\title{
Student Employment as a Possible Factor of Dropout
}

\section{Zsófia Kocsis and Gabriella Pusztai}

University of Debrecen, Faculty of Arts Doctoral School of Human Sciences, Egyetem tér 1, 4032 Debrecen, Hungary

kocsis.zsofia@arts.unideb.hu,pusztai.gabriella@arts.unideb.hu

\begin{abstract}
One of the possible reasons for student dropout, is the attraction of the labor market. Nowadays, the date of employment does not coincide with the date of graduation, sometimes the income of those without a degree are higher than those with a degree. In addition, it may also lead to the interruption of university studies that the students judge negatively the marketability of their studies, in which case, the appeal of the labor market is even more prevalent. During our research, we tried to identify the process of dropout using quantitative and qualitative methods. As a first step, we interviewed dropped out and 'at risk' students, but in our current analysis, we only processed those interviews where student work played a significant role in the life of the interviewee and this affected their dropouts. In addition, during our quantitative research, we were looking for individuals who had left their higher education studies without graduation in the last 10 years, and finally we worked with a database of 605 people. Both our qualitative and quantitative results show that financial reasons dominate during student employment that make them fall into a vicious circle. The results draw attention to the fact that working during, or instead of the university is an inevitable point of analysis for dropping out.
\end{abstract}

Keywords: dropout; student employment; financial burdens; student work

\section{Theoretical Overview}

Student employment is a double-edged sword, as on the one hand, it can reduce the academic performance of the students and on the other hand, it can have positive effects on the long run. In addition of earning money, the main advantage of working during studies is gaining work experience, enriching the CV with that work experience and gaining a better understanding of the structure of the labor market, which may be an advantage for students after graduation [1, 2, 3]. It also has a positive impact on oral communication skills, teamwork, improves time management capabilities and students can expand their social connections through work $[4,5]$. Nowadays, employment is playing an increasingly important role in the lives of the students. They devote a lot of time and energy to integrate work 
into their daily routine. According to the latest, Eurostudent VI, a little over half of the students worked during their university studies, and some of the students interrupted their studies for work-related reasons, in their case the attraction of the labor market appears strongly [6]. Several factors have already been identified in the 2012 material of OECD which enhance the chance of student dropouts. Among the top reasons was the attractiveness of the labor market, due to which the students are willing to leave the higher education institution without qualifications to ensure and improve their financial situation. There is no single definition to determine dropout of students. According to Lukács \& Sebö [7], there are three possible ways for student output: graduated, exited and dropped out. In the case of drop-out students, we mean cases where the student was excluded from the training due to passive semesters, non-acceptance of the cost reimbursement, the student was expelled due to disciplinary procedures or the student dropped their major or did not enroll. According to Fenyves et al. [8], the forms of dropout can be distinguished: the students themselves request dismissal, the institution asks for dismissal (due to study reasons, exam conditions), or the dismissal has health or financial reasons (study costs, the payment of the tuition fee was not realized on time). However, the studies focus on students who have finished their higher education without obtaining a degree and have thus become dropout students [7, 8]. Student dropout rates in Hungary are high, 36-38\% in undergraduate trainings and $14-17 \%$ in graduate trainings [9]. There is a suspicion that intensive student employment contributes to poorer academic achievements, postponement of the fulfillment of requirements, and eventually even leads to dropout. As a result, student employment can be interpreted as a risk factor that increases the risk of dropping out of school by keeping students away from university culture and embedding into the community [1, 10, 11, 13]. According to McCoy and Smyth [13] the drop-out rate is higher for students who take permanent, long-term jobs. According to Eurostudent VI survey data, 39\% of students in Hungary regularly work during the semester, while $14 \%$ work periodically during the study period [6]. Earlier research has confirmed that the attractiveness of the labor market is much stronger for students who do not receive any financial support, they are more likely to work during their university studies with higher intensity [2]. The results of the data collection of Eurostudent VI. show that the primary motivation for Hungarian students to work is to cover their living expenses. Most of them then said that without paid work, they would not be able to afford to be university students and the same amount of them work for experience. The fewest number of students work because they need to support someone else financially. In Hungary, working students spend more than 30 hours a week with work. Previous research has also confirmed that the tendency to drop out is higher among students who have long-term, intensive employment [6, 13]. $7 \%$ of Hungarian University Students interrupted their studies for at least a year and during the process, a quarter of students referred to workplace related reasons [6]. Work carried out during studies, especially during the passive semester, has a negative impact on graduating. Mostly, master students interrupted their studies 
and those who work more intensively than other student groups. A group of students $(25 \%)$ who interrupted their studies indicated that they requested to be passive due to workplace reasons. We can see that working during the university studies is an inevitable point of analysis in terms of dropout. In the process of dropout, it is worth mentioning the combination of factors that may increase the negative impact of employment, such as the family and financial background of the students, the motivation to work and their relationship to their studies. Previous research [3] also showed that students who have low, unfavorable status indicators and work because of their financial difficulties, and students who find their studies non-marketable are more vulnerable to dropping out. Working not only reduced the time spent on studying, but also the students' commitment to study, as the attractiveness of the labor market was even more pronounced among dropout students, they believed that their workplace provided a greater financial security and work was a 'promise' of their future employment, so they have chosen to interrupt their studies instead of completing them [3]. In our research, we focused on the role of employment in the process of dropout and we have examined how often and for what reason the dropout students worked during their studies.

\section{The Method of Research}

The Center for Higher Education Research and Development (CHERD) of the University of Debrecen in the framework of 123847 NKIFH (National Research, Development and Innovation Office) research project titled Social and institutional factors of student dropout in higher education conducts research focusing on factors affecting dropout since September 2017. During the course of our research, we tried to identify the process of dropout using quantitative and qualitative methods. As a first step, we interviewed dropout and 'at risk' students. Students were at risk for higher than the average number of passive semesters and procrastination, moreover, there were unfavorable changes in terms of the form of study and financing. In the qualitative phase of the research, we tried to get a clearer picture of the details of student employment and the reasons behind dropouts. At this stage of the study, we conducted a structured personal interview with several students, the staff of the Center for Higher Education Research and Development (CHERD) of the University of Debrecen was also involved in the research. We did not seek representativeness in the selection of interviewees, so we cannot draw clear conclusions about which social groups are more at risk of dropout due to work. We focus on the relationship between employment and dropout. We highlighted 7 interviews in which the students interrupted their studies due to the attractive impact of the labor market. With the help the method of Nagy [14] we recorded the interviews and we split the texts into units. We used an open code system and marked the topic of the units of the text. We analyzed 
the interviews on the basis of the characteristics of employment. With the help of the qualitative methods, we were able to get to know the target group's way of thinking and their motivation to work. Our goal is to continue to explore the underlying meanings and patterns of the connections. The lives and university careers of the interviewees are different. In addition to socio-cultural, financial and personal reasons, regular work played a significant role in the dropout of the surveyed students. We present to the university career of seven students, as they were those interviewees whose work was continuously present in their lives, in different ways. Basic information about the interviewees can be found in the list below, a numbering was used to ensure anonymity.

Student 1: 27-year-old male, completing his thesis and a successful final exam is needed to get his degree. He is currently spending his $14^{\text {th }}$ semester in higher education.

Student 2: 26-year-old male, who started their studies in 2011, first studying computer science, then chemical engineering, his expected graduation date was December 2017.

Student 3: 24-year-old female law student, who became a correspondent student for financial reasons and accepted a legal assistant job in Siófok.

Student 4: 20-year-old female studying pedagogy, who is in multiplesemester procrastination due to student work and the difficulties in studies.

Student 5: 23-year-old male student, currently studying chemical engineering, had multiple passive semesters.

Student 6: 37 -year-old male, graduated from the same training program as a correspondent student after multiple years, as they realized that obtaining the degree was essential to change jobs.

Student 7: 37-year-old male, from a small town near the county seat, currently living with his wife and his child in the county seat.

Based on the results of the qualitative research, our research team has formulated several statements in the questionnaire that may be the causes of dropouts identified by students. As a next step in the research, we contacted students who discontinued their higher education studies without graduating in the past 10 years. In the case of discontinued studies, we tried to cover a wide range of courses from natural sciences, engineering, and pedagogy to arts, medicine, healthcare, military, art, etc. We contacted students from 32 Hungarian higher education institutions (mainly from the Northern Great Plain) and five crossborder higher education institutions using the snowball method, a total of 605 people filled out the questionnaire. In our research, we used the DEPART 2018 database. Our research team formulated several statements in the questionnaire, 
which may be the causes of dropout identified by the students, which are listed in the appendix. These statements (listed in the appendix) had to be evaluated on a scale of 1 to 4 , and the following four clusters were created based on the statements in the quantitative phase:

1) Dropouts due to financial reasons and employment

2) Dropouts due to educational and institutional reasons

3) Multiple causes identified

4) Disappointed in their major and further education [15]

We used descriptive and bivariate analysis. In addition to the characteristics of the work, social backgrounds and institutional (funding of training) variables were used. In addition, motivation appeared as an individual variable.

\section{Results of the Qualitative Research}

\subsection{How has Work Played a Role in the Dropout Process?}

In analyzing the interviews, the main guideline was working during the university. Almost all of the interviewees took up working during their university studies for financial reasons. Some of them were motivated by the extra income or the desire to be independent from their parents, while some students were saving for their tuition fee. There was only one person who worked and discontinued their university studies to gain experience. We present the dropout process of the interviewees based on their attitude towards work.

In the first round, we interviewed those students who are typical examples of working students. Previous research has also shown that most students working during university seek employment due to financial difficulties. The first three students started working during their university years due to financial constraints. This was due to financial constraints, lack of parental support or the obligation to pay tuition fees.

'As a student worker, I worked several times in factories, shops, horticulture and construction sites. For a time, there was social support, I had a scholarship once, I had one better semester...' (Interviewee 1)

'At first, I did not work, later I needed to do so and so to speak, this continues to this day. It was annoying at first that almost everyone around me came with much more pocket money than I did. I decided to take a job. There were jobs where you had to go 2-3 times a month, obviously it was not a big help financially.' (Interviewee 2) 
In their view, work had a major negative impact on their studies. All three students were transferred to fee-paying trainings, 'perhaps this was the first domino that fell down' (Interviewee 2). A vicious circle has started, they had to work even more. The combination of work and studies was not easy, and as financial constraints were stronger, studying was clearly pushed into the background and they could not conciliate work with studying.

'I went to work whenever I could, and yes there were examples that this happened at the expense of studying. During the last semesters, I barely had any subjects and I tried to work as much as possible and study possibly less...' (Interviewee 1)

'However, when you went almost every day, at nights, you did not really have time to live. Getting up and going to class after a night shift was a problem many times, and we have not even talked about the time spent on studying, which was almost nonexistent then.' (Interviewee 2)

Work was constantly present in the life of the third interviewee as well, she regularly took typical student jobs during her university years to be able to pay for daily expenses and tuition fees. In her case, the attractive effect of the labor market has clearly prevailed, she decided to leave her full-time training and became a correspondent student, so she had the opportunity to work even more. The university student from Debrecen moved to Siófok for personal reasons, where first she worked as a receptionist, then as a legal assistant.

'I am currently working in Siófok at a notary's office, but I have been continuously working during the university years. Now I am a $4^{\text {th }}$ year law student. For three years, I was a full-time student and took student jobs. I became a correspondent student last September, as I wanted to work more to support myself and pay my tuition. During the summer, I was a receptionist at Lake Balaton, but after the season, I started working here at the office...' (Interviewee 3)

Work makes it easier for her to save money for tuition. What she sees positive in her decision is that after her several student jobs, she is finally doing work that is related to her studies. Although work, being a correspondent student and travelling a lot makes her life difficult, she still feels that she made a good decision.

'I found it important to gain new experiences, my student jobs were completely different... Hostessing, bartending, call centers, I have worked for almost all student job agencies. School took away a lot of time, and now I get to make my own schedule, 40 hours a week must be fulfilled, sometimes it is difficult to bring it together, but not impossible.' (Interviewee 3)

The reason for the dropout of the first three students was clearly working during university. From the beginning of their studies, they did some kind of gainful activity, which they could hardly make work with their university studies over time. As a result, they have become fee-paying students, further increasing their 
financial burdens, resulting in more intensive work. In spite of the work and the changes taking place, they continue their studies: 'If I have started, I will finish it!' (Interviewee 2).

The following two interviewees belong to the group of young people who are motivated to work by the desire to be independent from their parents. Even though they were not financially reliant on the extra income, they wanted to work, but their employment greatly compromised their university career. For the interviewees, working became a part of their lives during their university years. Initially, time management was difficult for them, to be able to study, work and rest.

'My week is almost spent with working. Usually 5 days a week, but they adapt to my schedule, so I let them know when I am free and they schedule me to work, so I can attend my classes. There are days when I work four hours, but generally nine. [...] Then I will tell you how my day went today, because, there was everything. I had a class from 8am until 10am, then I went to work at $11 \mathrm{am}$, I was there until $3 \mathrm{pm}$, then I had a class from $4 \mathrm{pm}$, which is until $6 \mathrm{pm}$. Then I have workout from $7 \mathrm{pm}$ until $9 \mathrm{pm}$. But actually I work more days, and I have a rest day when I try to catch up with myself.' (Interviewee 4)

In addition to working, the interviewees name the problems arising from their chosen major as the other reason for dropout. On the one hand, the problems were due to the negative perception of the major and the lack of supporting institutional environment. These factors increase the attractiveness of the labor market, which is why the interviewees chose their work instead of the university.

'I feel that I cannot do anything with this degree. And because of this, I am negative. Now I slip a year and I am here for four more years... and actually for nothing. However, my work is not related to my university studies, but it is positive that I have learned to work in a team, how to manage my time and the financial independence. I was able to hold my ground at least financially if I could not do the same at the university.' (Interviewee 4)

My fifth interviewee initially started to work to become independent from the parents. The reason for dropping out of the first major was not due to their employment, but rather institutional reasons. However, this reason was enough to consider student jobs more useful than continuous failing, even though studying and graduation were always among their goals.

'My high school class teacher, who was also my chemistry and math teacher pulled me down so much that I did not want to learn chemistry anymore. So I applied for the university to study computer science, I was accepted and I studied here for two years. Then there was my first break. Then I had a passive semester and went to work as a student, then there was a semester when I tried to informatics, but I did not like it, that subject and that 
teacher... and I quit permanently. Then I became an individual entrepreneur. I was a financial advisor, but I realized it is not something I really want to do, so I came back to study chemical engineering...' (Interviewee 5)

The interviewed student, as a result of negative work experience, realized that obtaining a degree is still an advantage for them in the labor market, so they applied for another training. But soon after beginning their chemical engineering studies, the attractive effect of the labor market prevailed again for the student. They decided to apply to work for TEVA to earn income and gain professional experience. According to them, they felt that they could not lose anything with this work, but could only gain additional knowledge, something they had no opportunity for at the university.

'The second time I became passive, within chemical engineering, it was a more conscious decision to see if it would be better to work... and then I went to TEVA for almost a full year, it was connected to my major. I believe you can learn something from every job. That is why they call back from many places. I also had a lot of benefit from TEVA, as I got to know people and I know what it takes to get in there. I also met the boss. To 60-40\% I needed the work to make money, that was stronger. And I also got a little insight where I should get in the future.' (Interviewee 5)

Among the interviewees, there was one who was less far-sighted, and only realized with the passage of time that having a degree is essential in today's world. They have been working in student jobs since high school, most of which were physical work. Similarly, to other interviewees, they called it positive that they expanded their network of contacts through work and made acquaintances which could be beneficial. However, their employment resulted in dropout. They have been working on weekends for months during their studies, which significantly reduced the time spent with studying. Moreover, they thought they do not need a degree:

'There will be no big difference in the salary of a new graduate and that of someone with vocational education in the future.' (Interviewee 6)

The warning signs have already appeared during the first exam period; this was when they decided to discontinue their university studies. They were able to find a company where they were chosen on the basis of their expertise, not the documents they obtained. There were no differences in salary, which further strengthened the belief that they do not need to complete their higher education. After several years, they were convinced that at least one degree is required to change jobs and advance in their careers.

The last interviewee returned to the labor market time and time again. He dropped out of two faculties and two majors, and work was constantly present in his life. He typically spent a period on the labor market after pausing his studies or before 
starting a new major. He said he chose to work, because the workplace was still more secure than completing certain subjects and then finding a job with a degree.

'There were certain subjects that were simply impossible to complete. Among the students, there were some who were in the three-year training for 7-8 years already. I failed the exam so many times for one of my subjects that I had to pause the training for two semesters. After that, I started another training, as a geographer, but I did not see the labor market outcome of the training.' (Interviewee 7)

The third major, which he finished as a correspondent student, was the andragogy training, which at the time was connected to his job. He did not find completing the training burdensome, but by the time he finished, he also changed jobs. At his current job, he is writing project tenders. In his free time, he is currently attending a vocational training to become a carpenter. His whole life and his relationship to work was accompanied by a positive perception of manual work, he is studying the carpentry profession because he says that they are doing 'nothing' at the office but producing papers.

\section{Results of the Quantitative Research}

In our research, we focused on the role of employment in the dropout process, examining how often dropout students did paid work during their studies. We defined the work frequency values as follows: never, yearly, monthly and weekly work. $28 \%$ of the respondents performed paid work weekly during their studies, $11 \%$ monthly, $12 \%$ yearly, but the highest proportion (48\%) were those students who did not work at all during their years of higher education. Previous studies [6, 16] had similarly low numbers of students whose work was related to their studies, $23 \%$ of them said that they had this kind of job.

Motivation has a particularly important role to play in why students start working. Usually the job of those students were related to their studies, who started working specifically to gain experience. However, in addition to gaining experience, financial reasons are dominant. Earlier research shows that the majority of university students work to cover their living expenses and to a lesser extent, finance their entertainment [3, 6]. According to Masevičiūtè et al. [6] in the Balkan countries, the main reason for students to work is to pay tuition fees, finance living expenses, gain experience and support others. The research of Fónai [17] also confirmed that there are three times as many dropouts in fee-paying trainings as in state-funded trainings. The financial burdens resulting from tuition fees and the employment can often be the causes of dropout. For this reason, we have examined what percent of dropout students were affected by fee-paying trainings and why they began to work during their studies. 33\% of the respondents 
continued their last training as fee-paying students. However, the payment of the tuition fees as a motivational factor affected $24 \%$ of the respondents, they were fully motivated by it during employment. $36 \%$ of the respondents were motivated by raising the financial resources needed for sustenance, while $35 \%$ were motivated by the desire to be independent from their parents.

It is clear from the answers that the majority of the dropout students were motivated to work due to financial reasons. Work for gaining experience was typical for only $16 \%$ of the respondents, as well as work for financing leisure activities. Getting new acquaintances and building relationships did not motivate the respondents almost at all.

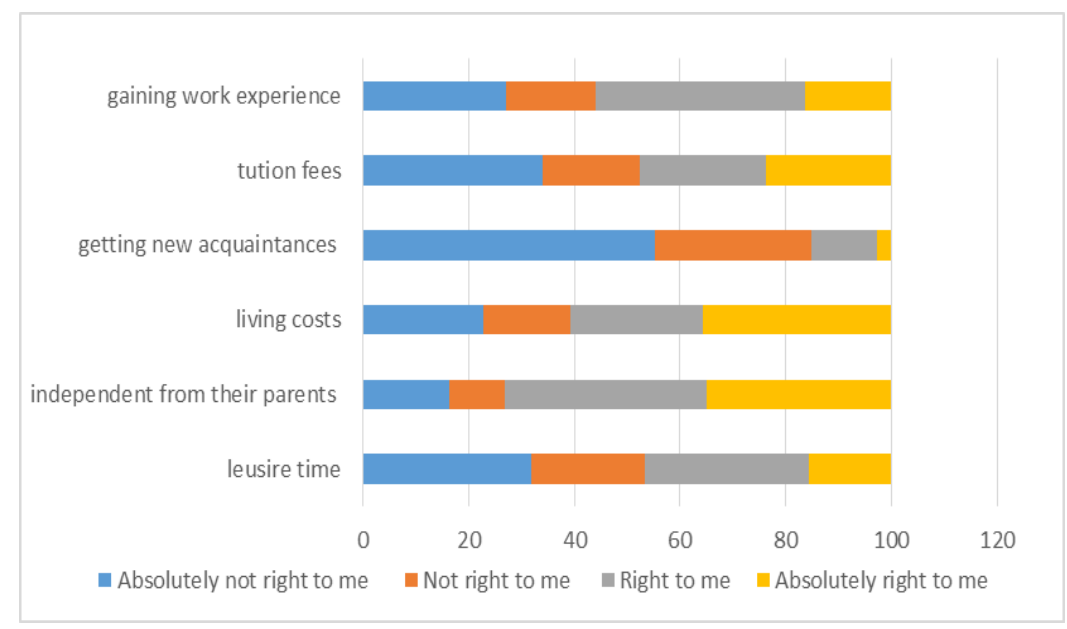

Figure 1

Motivations for employment (N=min. 384). Source: DEPART 2018

The special type of employment is working abroad, which can have positive effects on higher education studies such as learning languages, increased commitment, gaining professional experience, but also negative effects such as the general draining effects of the labor market and the strengthening of the migration bubble. 46 of the respondents $(8.6 \%)$ worked abroad during their academic years, but there was no significant correlation with dropout clusters. We may assume that the demonstration of the potential positive or negative effects and connections of foreign employment would require a larger sample.

In the remainder of the analysis, we have examined the connections between the above variables and the clusters of dropouts. First, we analyzed the frequency of employment in the clusters developed along the reasons for dropping out, where we found significant connections. 39\% of students dropping out due to financial reasons and work were affected by regular employment on a weekly basis, while fifth of them on a monthly basis. The negative effects of employment have also been proven by previous research, based on which the dropout rate is higher 
among those students who are in permanent, long-term employment, as working prevents them from attending courses to a large extent [10, 18]. A similar rate of employment characterized those respondents who dropped out due to educational reasons, $27.5 \%$ of them worked weekly during their university studies, and $28.3 \%$ of those who were disappointed with their studies started working. If the students judge the marketability of their degree negatively, the attractiveness of the labor market becomes even more pronounced and the presence of these two factors may lead to dropout. $26.3 \%$ of the respondents who were unsure of the reasons and dropped out were also doing some kind of money-making activity on a weekly basis.

Table 1

Frequency of employment in the clusters formed along the reasons for dropping out $(p=0,000)$

$(\mathrm{N}=541)$

\begin{tabular}{|l|c|c|c|c|}
\hline & $\begin{array}{c}\text { Dropouts due to } \\
\text { financial } \\
\text { reasons and } \\
\text { employment }\end{array}$ & $\begin{array}{c}\text { Dropouts due } \\
\text { to educational } \\
\text { and } \\
\text { institutional } \\
\text { reasons }\end{array}$ & $\begin{array}{c}\text { Multiple } \\
\text { causes } \\
\text { identified }\end{array}$ & $\begin{array}{c}\text { Disappointed in } \\
\text { their major and } \\
\text { further } \\
\text { education }\end{array}$ \\
\hline weekly & $39.0 \%$ & $27.5 \%$ & $26.3 \%$ & $28.3 \%$ \\
\hline monthly & $21.2 \%$ & $10.1 \%$ & $8.6 \%$ & $11.5 \%$ \\
\hline yearly & $6.8 \%$ & $13.4 \%$ & $17.1 \%$ & $12.4 \%$ \\
\hline never & $33.1 \%$ & $49.0 \%$ & $48.0 \%$ & $47.9 \%$ \\
\hline
\end{tabular}

Source: DEPART 2018

As a next step in our research, we investigated whether there is a difference between the motives of employment for the clusters formed. Respondents who dropped out due to financial reasons and the cluster of those who were disappointed in the training show some kind of correlation with employment motivations. It is clear that those students who dropped out due to financial reasons and employment were most likely to work due to their financial burdens. $41 \%$ of respondents in this cluster needed a job to cover their living expenses, while $32 \%$ due to their tuition fees. We assume that these students ended up in kind of a vicious circle, as they were working due to the increasing living expenses and tuition fees, however, the positive effect of employment was only significant financially, as they earned extra income, while working had a negative impact on their academic performance and thus they dropped out.

Presumably, these students were also characterized by what Masevičiūtè et al. [6] observed, namely that the majority of the students could not afford to study in higher education without paid work. In contrast, it was the most typical of those who were disappointed in their major and further education to work for reasons like gaining experience and new acquaintances. 22\% of those who were disappointed in further education worked specifically to gain work experience, while $19 \%$ to get to know new people during their work. 


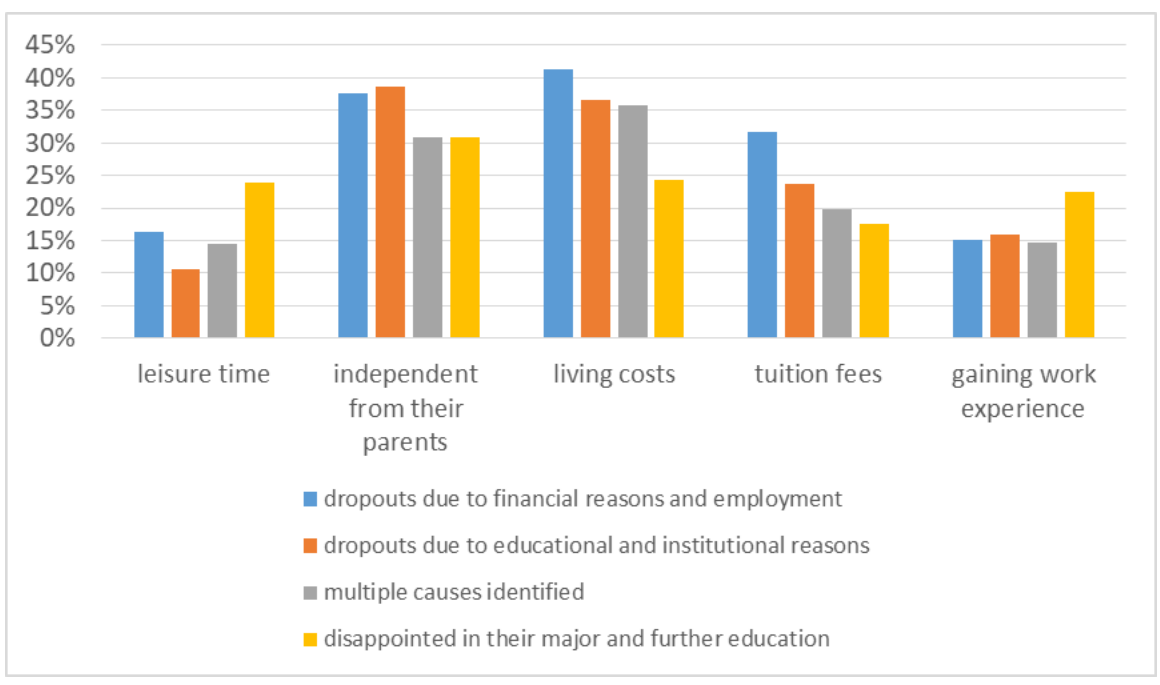

Figure 2

The connection of employment reasons with dropout reasons $(p>0,05)(\mathrm{N}=605)$

Source: DEPART 2018

The results clearly outline that the negative perception of the university studies or the disappointment in the training increases the attractiveness of the labor market, so it is not surprising that the students favored their employment responsibilities instead of their university studies. The data clearly indicates that at least a quarter of the students in each of the clusters worked during their university studies, either weekly or monthly, so to some extent, the negative impact of employment was shown as well as the attractive effect of the labor market. However, it should be noted that the correlation was not significant (Figure 2).

The draining effect of the labor market was not only present during the university years of the respondents but also after the interruption of their studies. $52 \%$ of the dropout students said that they had taken a job domestically after completing their studies, the proportion of those were very low who applied for another training, educated themselves or took a job abroad.

Based on our previous interviews and the results of our current quantitative research, we have identified four dimensions that could help reducing dropout rates and the impact of the draining effect of the labor market. In our opinion, the positive effect of student employment could be enhanced by practice-oriented university courses and the promotion of dual training. As work related to the studies can increase student success, but this cannot happen without the active involvement of higher education. Strengthening the relationship between the university and the places of practice, employment agencies and businesses is an essential element in ensuring that students do such work during their studies that are related to their university training. 


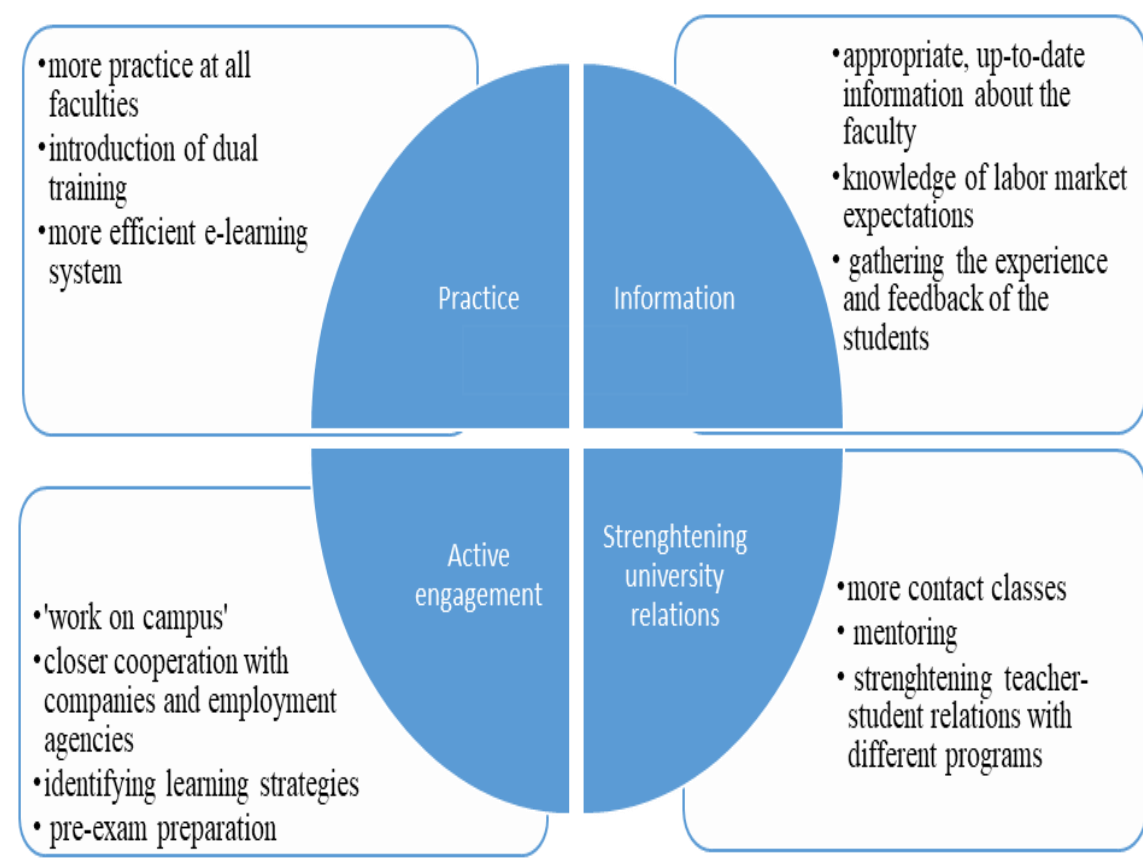

Figure 3

Suggestions for reducing dropout

Source: [19]

The engagement of the institutions lies not only in liaising with the partner institutions, but from the aspect of dropouts strengthening the relationship between teachers and students is also important, which could be improved through mentoring and other programs. The relationship between the two parties would enable teachers to recognize the learning strategies of the students, or to provide the students with preparatory or additional classes. These options could help working students to 'bring in' their fallback, which is due to their responsibilities at the workplace. In addition, it would be important to take into account the feedback and experiences of the students. Moreover, obtaining and transmitting information can be crucial for students at risk due to employment reasons. On the one hand, applicants should be aware of the outcomes of their training on the labor market, thereby reducing the risk of being disappointed in university education, and possibly less likely to discontinue their studies for a more attractive student job or job opportunity. The knowledge and tracking of labor market expectations can help students gain the knowledge and experience they need during their university years that would support their employment after graduation.

\section{Conclusion}

As seen in the results of Eurostudent VI, we realized that that more than half of the students work, due to financial difficulties. It is clear that financial reasons 
have a significant impact on the frequency of student employment [6]. According to international research results, the clear negative impact of employment is reflected in the deterioration of study achievement, and it may be a possible factor of drop-out. The negative impact of employment on academic performance has been supported by numerous studies $[1,6,10,11,14]$. During the analysis of the relationship between employment and dropout, we found that financial burdens, and consequently, work played a significant role in the dropouts of the students. The employment motivation for the majority of the respondents can be connected to finances, independence of their parents, covering daily expenses and the payment of the tuition fees. Motivational factors such as work experience and making new acquaintances motivated students to work to a lesser extent, however, these factors would be the most important for future return. Regular employment affected a quarter of respondents on average, with the highest rate of dropouts due to financial reasons and employment, and those who were disappointed in the major and further education. From the point of view of motivation, the cluster of those who were disappointed in the major and further education was outstanding as they were motivated mostly by work experience and making new acquaintances. We can conclude from the results that the negative perception of university education further enhances the already significant draining effect of the labor market. Therefore, it is not surprising that the attractive effect of the labor market was not only present during the university years, but also after the discontinuation of the studies; $52 \%$ of dropout students said that they took a job domestically after finishing their studies and the proportion of people who applied for another training or started to work abroad was very low. 8.6\% of the respondents worked abroad during their academic years, but the rate of employment abroad was not significant even after the interruption of their studies. $16 \%$ of those who were disappointed in their major and further education decided to work abroad, while to rest of the clusters have a lower rate of the same. Bocsi et al. [3] found that students' unfavorable socio-cultural background exacerbates the negative effects of employment. Furthermore, endangered those working students who were forced to work due to their financial difficulties. The interviewees' reports showed that employment plays and important role in dropout.

Interviewees identified employment as one of the reasons for their dropout. Some of them had no choice due to financial constraints, however more of them deliberately chose to work. They believe, as a career starter, experience is a prerequisite for a successful career, but it matters whether the fresh graduate has real professional experience or not. Some students believe it would be worthwhile to pay more attention to application and scholarship opportunities, as this would help their situation both professionally and financially, making student work less desirable. In addition, there would be a need for information that may be useful in their future employment, to have a clear picture of where and how they can work with their chosen profession. They emphasized the importance of professional internships and organization. According to them, regardless of their faculty and major, they would like to participate in professional internships, where they could 
gain the skills they have no opportunity for within the university walls. For this, it is essential to transform the teacher-student relationships.

Based on the unanimous opinion of the students, work and connections related to their profession would be the most useful, for which the contribution of the higher education institutions would be needed. At the moment, it is not easy to judge how strong a risk factor working during university is, as people deliberately chose employment instead of the university.

This decision raises another question: How could Higher Education Institutions benefit from the comments and experiences of these students?

\section{Acknowledgement}

This work was supported by the The Ministry of Human Capacities under Grant ÚNKP-18-3. Supported through the New National Excellence Program of the Ministry of Human Capacities.

Project no. 123847 has been implemented with the support provided from the National Research, Development and Innovation Fund of Hungary, financed under the K_17 funding scheme.

\section{References}

[1] Riggert, S. C., Boyle, M., Petrosko, M. J., Ash, D. \& Rude-Parkins, C. (2006) Student Employment and Higher Education: Empiricism and Contradiction. Review of Educational Research, 76(1), 63-92

[2] Roshchin, S. \& Rudakov, V. (2015) Russian University student and the combination of study and work: is it all about earning, learning or job market signaling? DOI:10.2139/ssrn.2566775

[3] Bocsi, V.; Ceglédi, T.; Kocsis, Zs.; Kovács, K. E.; Kovács, K.; Müller, A. É.; Pallay, K.; Szabó, B. É.; Szigeti, F.; Tóth, D. A. (2018) The discovery of the possible reasons for delayed graduation and dropout in the light of a qualitative research study. Journal of Adult Learning Knowledge and Innovation, 3(1), 27-38

[4] Beerkens, M., Mägi, E. \& Lill, L. (2011) University studies as a side job. Causes and consequences of massive student employment in Estonia. High Education, 61(6), 679-692, DOI: 10.1007/s10734-0109356-0

[5] Sanchez-Gelabert, A., Figueroa, M. \& Elias, M. (2017) Working whilst studying in higher education. The impact of the economic crisis on academic and labour market success. European Journal of Education, 52(2), 232-245, DOI: 10.1111/ejed.12212

[6] Masevičiūtè, K., Šaukeckienè, V., \& Ozolinčiūtè, E. (2018) Eurostudent VI Combining Studies and Paid Jobs. ISBN 978-609-468-169-1 
[7] Lukács, F. \& Sebő, T. (2015) Az egyetemi lemorzsolódás kérdőíves vizsgálata (Questionnaire survey on university drop-out) Iskolakultúra, 10, 78-86

[8] Fenyves, V., Bácsné Baba, É., Szabóné Szőke, R., Kocsis, I., Juhász, Cs., Maté, E. \& Pusztai, G. (2017) Kísérlet a lemorzsolódás mértékének és okainak megragadására a Debreceni Egyetem Gazdaságtudományi Kar példáján (Attempt to understanding the extent and causes of dropouts at the University of Debrecen, Faculty of Economics). Neveléstudomány, 3, 5-14

[9] Derényi, A. (2015) Bizonyítékokra alapozott kormányzás és a kommunikáció képzés (Evidance-based Governance and Communication Training) Jelkép, 1-21

[10] Darmody, M. \& Smyth, E. (2008) Full-time students? Term-time employment among higher education students in Ireland. Journal of Education and Work, 21(4), 349-362

[11] Perna, L. (2010) Understanding the Working College Student New Research and Its Implications for Policy and Practice. Sterling: Stylus Publishers

[12] Pusztai, G. (2014) The Effects of Institutional Social Capital on Students' Success in Higher Education. Hungarian Educational Research Journal, 4(3) DOI: 10.14413/HERJ2014.03.06

[13] McCoy, S. \& Smyth, E. (2004) At work in school. Dublin: ESRI/Liffey Press

[14] Nagy, Mária. 2006. A tanárok “hangja”, osztálytermi viselkedésük. Budapest: Országos Közoktatási Intézmény

[15] Kovács, K. et al. (2019) Lemorzsolódott hallgatók (Dropout students). Debrecen: Egyetemi Kiadó

[16] Pusztai, G. \& Kocsis, Zs. (2019) Combining and Balancing Work and Study on the Eastern Border of Europe. Social Sciences, 8(6)

[17] Fónai, M. (2018) Hallgatói lemorzsolódás a Debreceni Egyetemen (Student dropout at the University of Debrecen) In: Pusztai, G. \& Szigeti, F. (eds.). Lemorzsolódás és perzisztencia a felsőoktatásban (pp. 239-250) Debrecen: Debreceni Egyetemi Kiadó

[18] Curtis, S. \& Shani, N. (2002) The effect of taking paid employment during term-time on students' academic studies. Journal of Further and Higher Education, 26(2), 129-138

[19] Kocsis, Zs. (2019) How to support working students during their studies? In Erdei G., Erika Juhász, Salih Sahin \& Adnan Kan (eds), Ways of Promoting Excellence in Higher Education 
Appendix

\begin{tabular}{|l|c|c|c|}
\hline & N & Average & $\begin{array}{c}\text { Standard } \\
\text { deviation }\end{array}$ \\
\hline I was often short on time. & 539 & 2,3766 & 1,1247 \\
\hline I found a better opportunity to succeed. & 541 & 2,2773 & 1,15823 \\
\hline The teachers were incorrect. & 542 & 2,1384 & 1,07794 \\
\hline $\begin{array}{l}\text { Exams and papers always had worse results than } \\
\text { expected. }\end{array}$ & 540 & 2,1074 & 0,99327 \\
\hline I took too much work. & 541 & 2,0647 & 1,07904 \\
\hline $\begin{array}{l}\text { After admission, I realized I was not interested in the } \\
\text { major. }\end{array}$ & 554 & 2,0271 & 1,07964 \\
\hline After the failures, I no longer trusted myself. & 543 & 1,9982 & 1,13401 \\
\hline The administration was not supportive. & 537 & 1,9907 & 1,06588 \\
\hline $\begin{array}{l}\text { I did not even know what to do, I always lacked } \\
\text { information. }\end{array}$ & 541 & 1,9834 & 1,02094 \\
\hline I could not bear the costs. & 550 & 1,9818 & 1,14187 \\
\hline I did not care, studying was not important. & 546 & 1,8095 & 0,97697 \\
\hline I could hardly process the textbooks and notes. & 543 & 1,7348 & 0,9049 \\
\hline I ran out of exam opportunities. & 537 & 1,7095 & 0,9875 \\
\hline I was going out too much. & 543 & 1,698 & 0,93168 \\
\hline I was transferred to fee-paying training. & 545 & 1,6202 & 1,05752 \\
\hline I could not pay attention during classes. & 536 & 1,5746 & 0,826 \\
\hline I did not even want to study that major. & 548 & 1,5712 & 0,93307 \\
\hline I missed my friends and/or family. & 538 & 1,5576 & 0,842 \\
\hline The other students did not help me. & 545 & 1,5486 & 0,794 \\
\hline I ran out of state-funded semesters. & 531 & 1,5065 & 0,90598 \\
\hline Due to health reasons. & 1,3203 & 0,7665 \\
\hline
\end{tabular}

